\title{
Torture and Disappearance in Chilean Theatre from Dictatorship to Transitional Justice ${ }^{1}$
}

\author{
MILENA GRASS, ANDRÉS KALAWSKI AND NANCY NICHOLLS
}

This article presents the way in which both torture and the disappearance of individuals were staged in Chilean theatre from 1985 to 2011. The diachronic approach of this study is set to determine the ways in which the state's official reports on humans rights violations during dictatorship - the Rettig Report (1991) and the Valech Report (2004, 2011) - made an impact on theatrical production in terms of its political function. The study also analyses deployed theatrical devices to address extreme political violence onstage.

On 11 September 1973, the first socialist president ever to be elected by the people, Salvador Allende, was overthrown by the Chilean military forces supported by the country's right wing. During the Dictatorship that followed (1973-90), thousands of politically active citizens went into exile, and many of those who remained in the country to fight for the recovery of democracy were victims of torture and disappearance. ${ }^{2}$ The artistic field was dismantled. Many theatre practitioners and scholars left the country after being imprisoned or threatened by the secret police. Those who remained transformed their productions into resistance pieces, even though they were working under extreme surveillance. ${ }^{3}$

Despite the harsh control exerted over the artistic field, theatre performances played a fundamental role in denouncing the ongoing violations of human rights. From 1984, disappearance and torture were routinely staged in an attempt to represent openly in the public sphere the political violence that the Dictatorship wanted to hide. ${ }^{4}$ These performances gave the audience the possibility to collaborate on a search for an affective, cognitive and aesthetic experience that would integrate the narrative and emotional worlds that traumatic events dissociate. After the end of Dictatorship and up to the present, productions referring to local, recent history have been a constant in Chilean theatre, playing a fundamental role in the collective mourning process.

The five productions analysed here - Cinema Utoppia (Ramón Griffero, 1985), $99 \mathrm{La}$ Morgue (Ramón Griffero, 1987), La Huida (Andrés Pérez, 2001), Cuerpo (Rodrigo Pérez, 2005) and Villa + Discurso (Guillermo Calderón, 2011) - explicitly address the issues of torture and disappearance. ${ }^{5}$ The twenty-five-year span they cover saw Chilean theatre explore a range of methodologies to represent extreme political violence. Intermediality emerged as a key concept. Through our diachronic approach, we discuss the dynamic theatrical responses to a changing dictatorship. Over the twenty-five years, Chile moved 
from complete denial of covert human rights violations to public knowledge and acceptance of the crimes committed from 11 September 1973 to 10 March 1990.

\section{Chilean theatre and political violence during the Dictatorship}

Chilean theatre was almost totally destroyed when the Dictatorship began in 1973. Theatre artists and scholars were imprisoned, tortured and even assassinated, or went into exile. This severely limited what it was possible to offer audiences, as productions were hampered by censorship, curfews and space restrictions, along with the dismantling of distribution channels and publicly financed support systems, and even the closing of theatres and drama schools. ${ }^{6}$ As scholar Paula Thorrington Cronovich notes,

At the time of the coup d'état on September 11, 1973, anyone with affiliations to Salvador Allende's uprooted Popular Unity, or to anything leftist for that matter, became a target of the fierce cleansing process undertaken by the soldiers and police forces of the newly formed military junta. Artists and singers were shown no mercy in the violence, in fact they were pursued with a vengeance; the torture and assassination of the beloved, well-known singer Víctor Jara $\left[{ }^{7}\right]$ is the quintessential example of this kind of tragic death. $^{8}$

Nevertheless, by the beginning of the 1980s, the Dictatorship faced massive protests, and had to loosen its policies. As a result, a cultural resurgence began to materialize in marginalized, almost clandestine, spaces. This provided an alternative to the resistance strategy that long-standing companies had adopted by staging canonical authors (including Pedro Calderón de la Barca, William Shakespeare and Molière), whose plays worked as metaphors of the current political situation.

Among these new underground venues, El Trolley (1983-8) played a distinctive role. Along with playwright and director Ramón Griffero's productions, it hosted 'musical concerts, art exhibits, and video displays - [that] enabled a reconstitution of social relations where spectators had the opportunity to participate in resistance'. ${ }^{9}$ The sense of a reconstituted social bonding was particularly strong because the artistic performances took place in the midst of parties, allowing the counterculture movement to develop in a reclaimed, exultant public - if secret - space.

Ramón Griffero premiered Cinema Utoppia (1985) in El Trolley, ${ }^{10}$ in a clear move to denounce and resist the military rule. The play develops through three parallel stories in different settings and contexts. The first narrative is in the auditorium of Cine Valencia in 1946, where the same lonely characters come every day to watch a science fiction film (Utoppia). Screened in consecutive chapters, this story of political violence, homosexuality and drug abuse set in a futuristic 1980 is barely understood by its spectators. The second narrative features a series of scenes in the apartment of Sebastián, a bisexual Chilean man exiled to France whose female partner was abducted by the secret police before he had to flee. Finally, the third narrative is the Paris underworld of sex and drug commerce in the 1980s, seen through the window of Sebastián's apartment. As in a mirror game, the actual audience of the 1985 production was seeing another audience onstage living in the fictional 1940 s that was watching a third stage - an intended 
sci-fi feature movie taking place in the far future of $1980 .{ }^{11}$ The temporal fold allowed Griffero to perform explicit scenes, like a woman being abducted before becoming a desaparecida, ${ }^{12}$ hence overtly exposing the violence of the Dictatorship still in place.

Two years after the success of Cinema Utoppia, Griffero returned to the subject of unpunished murders perpetrated under military rule. 99 La Morgue (1987) presents a complex story that unfolds through different epochs, even though the set remains the same: the Morgue in Santiago. ${ }^{13}$ While Germán, the main character, insists that the corpses being brought every day show signs of torture and murder, the new Director of the Morgue replies that they have just drowned. This primary narrative is interrupted by scenes depicting characters from national history (Bernardo O'Higgins, the hero of Chilean independence), local imaginary (the Virgen del Carmen, Chile's religious patroness) and classical drama (the woman of Corinthian, Lady Macbeth), among other absurd, disparate personae. As theatre scholar Alfonso De Toro has pointed out,

99 The Morgue displays a well-known problem in all dictatorships, when forensics state that those who have been tortured or killed by the police died from accident or natural causes, like a heart attack or any other illness. The production and its content should be analysed and interpreted in the context of what it meant to perform it while Pinochet was still in power. Even though his dictatorship had already decreased the radical violence of the early years, it was risky business for both the author and director and the actors to go against an extremely dangerous reality. ${ }^{14}$

In fact, Griffero managed to explicitly represent abduction, torture and murder in a context where such denunciations were dangerous, in a moment where the media either actively collaborated in the cover-up or were too afraid to address human rights issues. ${ }^{15}$ By employing a distancing device - the movie scenes in the first case, and an expressionist, bizarre pastiche in the second - he represented political violence onstage as a blunt act of defiance even while Pinochet still had the nation in his grip.

\section{Transitional times: beyond the boundaries of dictatorship}

The state violence exerted by the military and the secret police in Chile between 1973 and 1990 remains a controversial issue. ${ }^{16}$ Both during the Dictatorship and in its aftermath, Chilean historians rarely approached recent history as an important research subject. ${ }^{17}$ The issue of human rights violations was absent from public debate because raising the issue meant accusing the military, something very few people dared to do before 1990. Even after 1990, many still avoided such discussions because they might endanger the fragile process of redemocratization. ${ }^{18}$ And even though the Transition came with the promise of justice, the newly elected government had to surrender to the power the armed forces still possessed, as Pinochet remained commander-in-chief of the Army until his resignation in $1998 .{ }^{19}$

On 10 October 1998, Spanish magistrate Baltasar Garzón indicted Pinochet for human rights violations committed in Chile; Pinochet was subsequently arrested in London. The event marked a turning point in transitional justice. ${ }^{20}$ Responding to this new context, theatre directors turned again to human rights violations. This time, 
however, instead of being compelled to denounce concealed crimes, theatre artists focused their work on the entire span of the Dictatorship to put political violence in a broader context, and to move beyond the limited field of criminal justice.

In this new context, Andrés Pérez premiered La Huida (The Escape) in 2001. ${ }^{21}$ As the director noted, the play's first version was written in 1974 as a response to the coup. ${ }^{22}$ Through his research, he discovered that in the history of Chile there have been other periods of prosecution. [Therefore this play] also stages my own knowledge of the fears and uncertainties of being persecuted, looked upon, cornered, under an explicit prohibition of performing on the streets, of being held in jail'. ${ }^{23}$ La Huida's plot is set in 1929, amidst the alleged raid ordered by General Carlos Ibáñez del Campo, where homosexuals were said to have been thrown into the sea, alive, blindfolded and with their feet cast in concrete. In this context, Joaquín, a middle-aged homosexual, is killed when trying to help a young gay couple to escape. Scattered across this line of action is a series of autobiographical scenes where the playwright evokes his own memories intertwining sexuality and dictatorship. ${ }^{24}$ As well, the other actors - speaking for themselves or for some fictionalized alter egos, we do not really know - reflect on the experience of playing a gay character. This twofold display is made even more complex by the use of documentary materials, in particular press photos of Carlos Ibáñez del Campo (only referred to as the General) and video testimonies from Andrés Pérez's mother about her son's sexual identity and the disappearance of gays in the 1930s, of which she heard when she was fifteen years old. Although Pérez intends to make the point that the persecution and disappearance of minorities is not new to Chilean history, the overlap of similar situations several decades apart was mostly seen as an aesthetic technique to address the present. Nevertheless, the key role given to homosexuality in the production, and the stress put on the fact that this dark episode has never been openly addressed, brought us to believe that Pérez is raising the question of justice itself. Strong political forces allied in transitional Chile sought truth, repair for the victims and the punishment of those responsible for criminal acts. The atrocities perpetrated against gay minorities, however, are still covered by the shadows of uncertainty and myth. So the relationship is inverted: the horrors of the past no longer make it possible to assess recent political violence. Instead, the establishment of factual, public knowledge of Dictatorship crimes should set the standard for the recognition of previous murderous state policies. ${ }^{25}$

Ten years after La Huida immersed itself in the past, the same concerns projected Guillermo Calderón's Villa+Discurso (Villa+Speech, 2011) into the future. ${ }^{26}$ This play addressed the question of how post-conflict memory should be addressed. In Villa, three characters - each aged thirty-three and bearing the same name - debate the destiny of Parque por la Paz Villa Grimaldi, the most emblematic torture and disappearance site of the Chilean Dictatorship. It is also the first former clandestine site in Latin America to be opened to the public as a commemoration of torture and disappearance. The alternatives they propose range from a hyperrealistic reproduction of the torture centre, a white postmodern museum, ${ }^{27}$ or the Parque por la Paz as it is, to a grass field where everybody can remember whatever he or she wants because 'we all react in a different way' to the past. ${ }^{28}$ The second play, Discurso, is a farewell speech from Chile's first female president, Michelle Bachelet, who herself was kidnapped and held for six days in Villa 
Grimaldi (10-16 January 1975). The three actresses from the first play appear in the second to give President Bachelet's monologue a polyphonic voice.

Beyond the obvious fact that both parts of these two plays mirror each other, Calderón aims for a radical relationship between space and time, fiction and reality. That the play premiered and performed, at least initially, at former detention and torture centres puts the referent in a mise en abîme that is even more dizzying when Villa+Discurso is represented in Parque por la Paz Villa Grimaldi itself. In this performance, the discussion about refurbishing the memory site that unfolds in front of the audience refers to the same space that contains and engulfs spectators, actors and stage. The audience is not just sitting there to watch a performance, it is also part of the document/monument dramatized by the production that tries to settle the way in which the memory of torture and disappearance is to be retrieved and constructed for future generations.

In between the temporal displacements of La Huida and Villa+Discurso, Rodrigo Pérez explored a totally different approach to the theme of human rights violations in Cuerpo (Body, 2010). ${ }^{29}$ Unlike all the previous productions analysed here, Cuerpo does not rely on a plot. More concerned about the effects of torture on both the individual and the collective social body, the play brings together intense sequences of movement and a series of text fragments - from the Valech Report and the Letter to the Actors: To Louis de Funès by French philosopher and playwright Valère Novarina ${ }^{30}$ to the unsuccessful recollection attempts of a victim of political violence and the public statement of a Chilean Christian Democrat politician accused of child abuse. Built on the idea that remnants and revenants haunt post-conflict societies, the fragments of texts are uttered (sometimes more than once) in a voice devoid of any feeling, while the bodies are invested with violence and exhaustion. Simultaneity and repetition seem to be joined together in a vain effort to remember what has been forgotten, and to organize the unbearable, incomprehensible experience of torture.

\section{Beyond theatre's political function: how does it work?}

The shift from Dictatorship to Transition imposed changing priorities on theatre artists willing to participate in the public sphere. Whereas the main concern during the dark years of Pinochet's military regime was disclosing human rights violations, the achievements of transitional justice intended to raise the issue of post-conflict policies and the management of traumatic memories in order to avoid such atrocities in the future.

Nevertheless, despite these shifts, some questions of aesthetic efficacy when trying to tackle questions of torture and disappearance remain the same. Cuerpo, scholar Agustín Letelier states,

Is a research on the ways to make concrete a non-dramatic text, a report; to provide it with affect, and theatre value. Testimonies have been corroborated. Main social actors involved in the facts have accepted their truthfulness. The report has been broadly published, so it is supposed to be widely known; however, it is necessary to trigger an emotional resonance to embed it into consciousness. This is the work done here. ${ }^{31}$ 
The underlying assumption of this claim is that there is a shared truth of which emotional resonance is only half. The call for staging affect is part of the larger effort to represent extreme experiences of embodiment. This is in tandem with conveying basic information about these experiences.

The inescapably complex intensity of torture makes it impossible to represent within the dichotomic categories we apply in everyday life: body versus mind, truth versus fiction, past versus present, and so on. The result is a saturated and recursive theatrical universe that attempts to stage the impossible: a coherent narrative that would give meaning to traumatic experience.

The attack on the compulsion to create narrative is realized through different means. On the one hand, there is the use of diverse media that mirror each other and, at the same time, contradict common sense. In Cinema Utoppia, for instance, the audience is presented with a clash between theatre and film that turns the reference to contemporary events into a second level of fiction. And the paradox is double: the film is also fake. The spectators of Ramón Griffero's production recognize the inability of the film-goers to understand the urgent political content featured in Cine Valencia, as the silent complicity of hundreds of Chileans dismissed political violence as fiction, mere 'stories'. Nevertheless, in times of censorship, the staging of abduction scenes was possible precisely because they were relegated to fiction, presented through a veil like a black-and-white movie.

Whereas the twisting and mirroring of fiction and reality is embedded in the plot itself of Cinema Utoppia, in La Huida and Villa+Discurso it depends on the combination of fiction and reality. The threefold imbrication of Andrés Pérez's roles in his 2001 production, as playwright, director and actor, is reinforced by the autobiographical element. Reflexivity intermingles with autoreflexivity when he refers to his attending gay parties after curfew hours during the Dictatorship dressed as the homosexual hero he plays in the mythical fiction he has just completed.

An analogous intermingling of fiction and reality occurs in Villa+Discurso. While relying on thorough research about the debate on the renovation of Parque por la Paz Villa Grimaldi, the installation of the production in the park itself produces a mise en abime similar to the one in Cinema Utoppia. Different overlapping levels of reality encapsulate each other, and render it difficult to maintain the boundaries between fiction and documentary. ${ }^{32}$ This is further reinforced by the reference to President Bachelet. Her monologue is polyphonically delivered by three actresses who are much younger than the woman they portray. These differences highlight the representational character of the performance, which does not attempt realistic impersonification. The production portrays the president by representing her - through her actual words - and by explicitly not representing her - by constructing a multiple body onstage that is clearly not hers. As a result, the audience is confronted with a mise en scène of liminality, which makes it difficult to distinguish between truth and fiction.

In the case of Cuerpo, torture's complexity is not conveyed by the paradox of fiction and reality, through the development of concurrent plots, or by the splitting of the relation between actor and character, but by the simultaneity of different languages 
at contrasting intensities. When the following text is repeated in an emotionless voice whose rhythm does not change, it is accompanied by a sequence of hectic movements also repeated at an increasing rate:

According to data and as shown in the following chart, $\left[{ }^{33}\right] 44.2 \%(12,060)$ were from 21 to 30 years of age at the time of detainment, i.e., they would be in what is today called the young adult segment. $25.4 \%(6,913)$ were from 31 to 40 years old and $12.5 \%(3,397)$ from 41 to 50 years of age. $9.7 \%(2,631)$ were also from 18 to 20 years of age, of which $4 \%$ $(1,080)$ were below the age of 18 . Adults above the age of 50 represented $4.3 \%(1,174) .^{34}$

In this case, it is almost impossible to match the data, the actual facts and the physical demand on the dancers' bodies, making clear the difficulty of turning statistics the social body - into flesh - the individual body. However, the effort to couple the detailed description of torture in technical language with the performers' exhaustion is also impossible because the idea of submitting an actual body to such treatment is unthinkable.

Along with this dissonant flood of stimuli, the audience must face an intensification of movement sequences and texts that get progressively more unbearable:

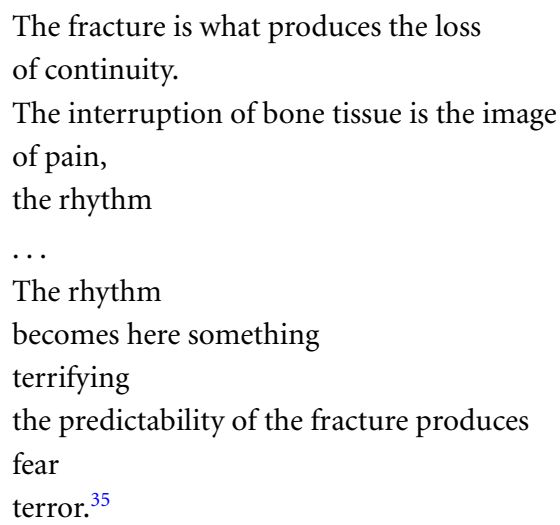

The effectiveness of torture lies not only in the unexpected, but also in on the predictability of pain. The fugue structure of Cuerpo reproduces the iteration of sequences with minor changes; this allows the audience both to predict what will come next and to be kept aware of slight changes. Hence the production addresses the issue of torture not only by speaking of it, or submitting the performers' bodies to physical distress, but also by mimicking its structure.

One of the characters in Villa wants the visitor's experience of the former torture centre to be like a ride on an 'emotional roller coaster'. The mechanisms and resources that are key elements of various theatre productions staged across twenty-five years, from the Chilean Dictatorship to the present moment, share the same target. When it comes to torture and disappearance, there will always be impossibilities, namely to know, to understand, to represent. Nobody can vicariously experience torture. We will never fully understand the human capacity to inflict pain. No one will ever fully reveal what 
happened to the disappeared. What theatre at its best can do is involve audiences in a complex, paradoxical experience where affect is invoked along with critical thinking, disturbing our normal perception and interpretation of the world.

NOTES

1 This paper is the result of a research project supported by the Dirección de Arte y Cultura of the Vice-rectoría de Investigación of the Pontificia Universidad Católica de Chile, and by the MEMOSUR Project ('A Lesson for Europe: Memory, Trauma and Reconciliation in Chile and Argentina'), funded by the Marie Curie Actions - International Research Staff Exchange Scheme (IRSES). Mariana Hausdorf, actress and historian, was the research assistant.

2 The Dictatorship ended in 1990, when elected president Patricio Aylwin took office. One of his first measures was the creation of the National Commission on Truth and Reconciliation to investigate human rights violations by agents of the state or people that were under state authority from 11 September 1973 to 11 March 1990. The commission's report, known as the Rettig Report (www.ddhh.gov.cl/ddhh_rettig.html), was delivered on 8 February 1991. It documented 2,296 victims of aggravated homicide, leaving unassessed the victims of torture and disappearance. In 2004, the National Commission on Political Imprisonment and Torture, summoned by President Michelle Bachelet, published the Valech Report (www.indh.cl/informacion-comision-valech), which documented 40,018 victims under that same period of time. According to the report's revised 2011 version, 3,065 of those victims are still missing.

3 See Ana Puga, Memory, Allegory, and Testimony in South American Theater: Upstaging Dictatorship (New York: Routledge, 2008). The Argentinian and Chilean cases are analogous in many respects; see also Jean Graham-Jones, Exorcising History: Argentine Theater under Dictatorship (Lewisburg, PA: Bucknell University Press, 200o).

4 In the 1970s the Association of Families of Missing Detainees, largely comprising women, was able to draw public attention to the detenidos desaparecidos through hunger strikes, appeals to international agencies and street protests, creating thereby one of the emblematic memories that characterized Pinochet's Chile and the transition. See Steve Stern, Battling for Hearts and Minds: Memory Struggles in Pinochet's Chile 1973-1988 (Latin America Otherwise) (Durham, NC: Duke University Press, 2006).

5 In all five cases, the playwrights are also the directors of the Chilean premieres of the plays. In terms of the temporal span, the first play (Cinema Utoppia) and the last (Villa+Discurso) are now considered canonical both for Chilean theatre as a whole and for the more restricted category of political theatre. For the bicentennial of Chilean Independence, Fundación Teatro a Mil financed the staging of the most important plays of the Chilean canon from 1810 to 2010. Cinema Utoppia was one of those twelve productions. See http://192.cl/agenda/teatro/santiago-a-mil-2010-programacion-nacional-para-elbicentenario, last accessed 5 May 2015.

6 Despite the harsh conditions, even in the 1970s some productions by independent theatre companies premiered socially minded, daring plays, namely Pedro, Juan y Diego (1976) by Ictus and David Benavente, ¿Cuántos años tiene un día? (How many years a day?) (1978) by Ictus and Sergio Vodanovic, Los payasos de la esperanza (Clowns of Hope) (1977) by Taller de Investigación Teatral, and Tres Marías y Una Rosa (Three Marys and a Rose) (1979) by Taller de Investigación Teatral and David Benavente. Víctor Jara's importance as a singer has overshadowed his remarkable work as a theatre director.

8 Paula Thorrington Cronovich, 'Out of the Blackout and into the Light: How the Arts Survived Pinochet's Dictatorship', Iberoamericana, 13, 51 (2013), pp. 119-38, here p. 120.

9 Ibid., p. 128.

10 Ramón Griffero, Cinema - Utoppia (Santiago: LOM Ediciones, 2010). Ramón Griffero was born in Santiago in 1953. After being politically active in the early 1970s, he went into exile in London in 1973, where he studied social science at the University of Essex. In 1979, he moved to Belgium, where he was admitted to the Centre for Theatre Studies at Université Catholique de Louvain. In 1982, he returned to 
Chile where he founded the company Teatro Fin de Siglo, which resisted the military dictatorship through its artistic productions. See www.outofthewings.org/db/author/ramongriffero, last accessed 5 May 2015; and Catherine Boyle, Chilean Theater, 1973-1985: Marginality, Power, Selfhood (New Jersey: Fairleigh Dickinson University Press, 1992).

The scenes were not projected, but performed live behind a semi-translucent screen.

Desaparecidos, short for detenidos desaparecidos, is the name given to the victims of the Dictatorship's secret police, whose corpses were made to disappear in order to make it possible to deny assassinations by state agents, thus enabling them to avoid future criminal proceedings.

13 Ramón Griffero, 99 La Morgue (unpublished script).

14 Alfonso de Toro, 'La poética y práctica del teatro de Griffero lenguaje de imágenes', Dramateatro, 1999, pp. 113-37, here p. 134 (our translation).

15 Even though Cinema Utoppia clearly states that its main character is in exile and that his woman was abducted, Carvajal's 1985 review of the play is astonishingly vague: 'Sebastián (Esteban Marió) has been living for a long time in France and tried everything at every level, but there is no doubt that he has taken the path to self-destruction. The woman he loved and lost in Buenos Aires, "she" (Carmen Pellisier) haunts him all the time, being his ghost and torment'. See Rigoberto Carvajal, 'Ramón Griffero: "Yo no quiero escandalizar, sino conmover"', El Mercurio, 7 June 1985, n.p. (our translation). Along with this lack of specificity, contemporary reviews also focused on the explicit sexual content of the play, avoiding any mention of its political relevance and resonances.

The commemoration of the fortieth anniversary of the coup came along with an explosion of testimonies and archival material broadcast by open television channels. After this overexposure to the atrocities perpetrated during the Dictatorship, not even the most recalcitrant rightist who long defended the theory of the internal war could go on denying the crimes.

17 One of the difficulties of historiography in addressing these issues is how to narrate torture and other human rights violations involving horror without causing the reader to reject the work. Recalling La Legua shantytown in the 1980s, historian Mario Garcés states, 'There was a very strong contained pain, above all for the missing, about the way it occurred, the difficulty of attaining justice, that they be recognized, for the violations, the segregation because they were poor. I did not know how to write it and I have always had trouble writing ... I believe that historiography is a very difficult field, it is very difficult to put a name to the horror, to represent ... the act of horror in writing' (interview, 24 May 2012).

18 During the Transition, left-wing politicians fostered the suppression of civil actions seeking justice in order to protect recently regained democracy or to leave the task to official institutions specifically commissioned to uncover the truth. Theatre director Rodrigo Pérez recalls having decided to work in a production to address the issue after hearing José Miguel Insulza, then secretary of the interior, asking citizens not to file any judicial complaint for torture cases because the Dialogue Table had recently been created (see note 20 below). Rodrigo Alvarado E., 'El director teatral explica su ambicioso nuevo proyecto: “La Patria” torturada de Rodrigo Pérez', La Nación, 9 June 2005, pp. 28-9, here p. 28. Interestingly enough, regarding the relationship between theatre productions and transitional justice, reviews of La Huida also referred to the Dialogue Table. See Javier Ibacache, 'Accidentado debut tuvo obra "La Huida", de Andrés Pérez', La Segunda, 5 February 2001, n.p.

19 See Michael Lazzara, Chile in Transition: The Poetics and Politics of Memory (Gaineseville: University Press of Florida, 2006).

20 Transitional justice is a complex process that combines the creation of truth commissions to acknowledge the victims and to set repair policies with judicial proceedings to determine criminal responsibility. Along with the Rettig and Valech reports, it is important to mention the work of the Dialogue Table (1999-2001), where key members of civil society sat together with representatives of the armed forces in an effort to determine where the last remains of disappeared people were buried or disposed of. 
21 Andrés Pérez, La Huida (unpublished script). Andrés Pérez (1951-2002) was a Chilean actor, choreographer and director. He received a BA in acting from the Universidad de Chile and became a member of Arianne Mnoushkine's Théâtre du soleil in 1982, playing the role of Ghandi in La Indiade (1987). In 1998, he returned to Chile and founded the Compañía Gran Teatro Circo, whose most emblematic production was La Negra Ester (1988), based on Roberto Parra's autobiographical décimas (the most-popular form of Chilean verse). Due to the enormous impact of his work in contemporary Latin American theatre, his birthday (11 May) has been chosen to commemorate Chile's National Day of Theatre.

Andrés Pérez revisited his play three times in the following twenty-six years. The staged version is dated May 2000.

23 See Leopoldo Pulgar, 'Andrés Pérez desclasifica sus obras', La Tercera, 11 December 2000, n.p. (our translation).

24 Two months after the premiere, the playwright/director also took over the leading role in the production, so the autobiographical scenes previously played by Erto Pantoja were then performed by Andrés Pérez.

25 Quite interestingly, theatre critiques referred to the Holocaust when reviewing La Huida, and even dared to state that the production portrays 'a Warsaw Ghetto in the Chilean way'. See "La Huida": montaje electrizante sobre los "muertos vivientes", La Nación, 5 February 2001, n.p.; Willy Haltenhoff, “"La Huida”, montaje expresionista para una historia olvidada', La Nación, 6 February 2001, n.p.; Pedro Labra, 'La Huida: diferentes y perseguidos', El Mercurio, 6 February 2001.

26 Guillermo Calderón, Teatro II. Villa - Discurso - Beben (Santiago: Lom, 2012), pp. 7-70. Guillermo Calderón (1971) is an actor, playwright and director. He has written and directed Neva (winner of Best Play of the Year 2006; three Altazor Awards in 2007,including Best Director and Best Playwright; and the 2008 José Nuez Martín Award), Clase (Best Play of the Year 2008), Diciembre (2010 Bank of Scotland Angel Award, Edinburgh International Festival), Villa+Discurso, and Escuela (2013, Theater der Welt festival in Mannheim, the Onassis Cultural Centre in Athens, the Calouste Gulbenkian Foundation in Lisbon and the Théatre de la Cité Internationale in Paris) - all international runaway hits. His productions have been presented in twenty-five countries and at festivals. He graduated with a degree in arts specializing in acting from the Universidad de Chile. Calderón attended the Royal Court Theatre International Residency in 2009, where he wrote Discurso. He also wrote and directed two plays for the Düsseldorfer Schauspielhaus in Germany - Beben and Kuss - and worked on a commission from the Public Theater in New York City.

27 A copy of the Museum of Memory and Human Rights inaugurated in 2010 by President Michelle Bachelet.

28 Guillermo Calderón, Teatro II, p. 70.

29 Rodrigo Pérez, Cuerpo (unpublished script). Rodrigo Pérez is a Chilean actor and director. He holds an undergraduate degree in psychology, and studied acting in the Academia de Actuación Club de Teatro de Fernando González. A former actor in both Ramón Griffero’s company Teatro de Fin de Siglo and in Teatro La Memoria, he has directed a range of plays - from the Greek works to twentieth-century European dramas (particularly those of Bertolt Brecht and Heiner Müller). He has been invited to work in the Centre dramatique national de Normandie (1999), and in Germany (Cologne, Stuttgart, Esslingten, 1998). In 2005, the Chilean National Endowment for the Arts funded his project Motherland (Fondart de Excelencia), which consisted of three productions (Cuerpo, Madre (Mother) and Padre (Father)), all of which focused on recent Chilean history and human rights violations during the Dictatorship.

30 The parallel between torture and disappearance and the performing body is fully stressed by the production through the fragments of Novarina's text. For instance, 'The one who comes onstage is always a resurrected. The surprise comes from the actor's absence, not from his presence. The man is an animal gifted with absence'. Rodrigo Pérez, Cuerpo, n.p. Agustín Letelier, 'La Patria 1, el cuerpo', El Mercurio, 14 August 2005, n.p. 
32 Documentary material - photographs and film footage - plays an important role in all of the productions analysed here. Even though the constructedness of all documentary material is inescapable, the aura of factual evidence it has fosters its insertion in theatre productions that thematize torture and disappearance as an element that asserts the truthfulness of the events. See Patrizia Violi, 'Images as Testimony: Use of Photographs in Literary Reconstruction of Cultural Memory', in M. Daly and C. Demaria, eds., The Genres of Post-conflict Testimonies (Nottingham and Seattle: CCCP Press, 2009), pp. 153-80.

33 In this moment, actors point to the chart that is projected on the back wall of the stage above their heads. The seven-page script has no didascalia, being just the sum of the uttered component of the production.

34 Pérez, Rodrigo, Cuerpo, n.p.

35 Ibid.

MILENA GRASS KLEINER (mgrass@uc.cl) is a translator and theatre scholar, with an MA in Latin American Studies (Universidad de Chile) and PhD in Literature (P. Universidad Católica de Chile). She has published Spanish translations of English, American and French plays, as well as books on Chilean history and theatre studies. Her research is focused on the relationships between theatre, history and memory.

ANDRÉS KALAWSK I (akalawsk@uc.cl) is an actor and playwright with a PhD in history. His plays have regularly premiered at professional theatres, received awards, and have appeared in anthologies and individual publications. His research interests include the relationships between history, theatre, playwriting and public arts policy.

NANCY NICHOLLS (nnicholls@uc.cl) earned a BA in history from Pontificia Universidad Católica de Chile, and a PhD in sociology from the University of Essex. Her writing and research focus on history and memory and the historical present, with an emphasis on oral histories. Her attention to oral, literary and audio-visual sources has opened up her work to the field of subjectivity, representation and the role of the imaginary in historical phenomena. 